\title{
Vaccine Innovation for Pandemic Preparedness: Patent Landscape, Global Sustainability, and Circular Bioeconomy in Post-COVID-19 era
}

\author{
Cristina Possas ${ }^{1}$ (D) - Adelaide Maria de Souza Antunes ${ }^{2,3}$ (D) \\ Alessandra Moreira de Oliveira ${ }^{2,3}$ (D) - Cristina d'Urso de Souza Mendes Santos ${ }^{3}$ (D) \\ Mateus Pinheiro Ramos ${ }^{2}$ (D) - Suzanne de Oliveira Rodrigues Schumacher ${ }^{2}$ (D) \\ Akira Homma ${ }^{1}$ (D)
}

Received: 1 March 2021 / Accepted: 27 April 2021 / Published online: 15 July 2021

(C) Springer Nature Switzerland AG 2021

\begin{abstract}
In this article, we present breakthroughs and challenges in vaccine development for COVID-19 pandemic, discussing issues related to pandemic preparedness and their implications for circular bioeconomy and sustainability. Notwithstanding the unprecedented accelerated speed of COVID-19 vaccine development, just 9 months after the emergence of the pandemic in Wuhan, China, benefiting from previous developments in SARS and MERS vaccines, significant gaps persist in global vaccine preparedness. These gaps include issues related to immunity and protection, particularly to the limited vaccine protection against recent emergence of concerning new viral variants in the UK, South Africa, and Brazil and the consequent need for vaccine redesign. We examine these gaps and discuss the main issues that could impact on global vaccine availability in the current pandemic scenario: (1) breakthroughs and constraints in development and production of leading global COVID-19 vaccines; (2) innovation and technological development advances and gaps, providing information on global patent assignees for COVID-19, SARS, and MERS vaccine patents; (3) local capacity for development and production of COVID-19, SARS, and MERS vaccines in three emerging agro-based countries (India, Brazil, and South Africa); and (4) future scenarios, examining how these issues and vaccines redesign for new SARS-CoV-2 variants could impact on global access to vaccines and implications for circular bioeconomy and sustainability in the postCOVID era.
\end{abstract}

Keywords Vaccine innovation · COVID-19 · SARS · MERS · Pandemic preparedness · Circular economy

Cristina Possas

cristina.possas@bio.fiocruz.br

Extended author information available on the last page of the article 


\section{Introduction}

Vaccines, due to their relatively low costs when compared with pharmaceutical drugs, high cost-effectiveness, and huge impact on economy and society, have emerged in the COVID-19 pandemic as a key bioeconomic product and a crucial component of circular economy, in the direction of a more sustainable and equal world. Vaccines are widely recognized as the most successful and low-cost public health interventions, saving millions of lives, and considered one of the greatest medical achievements of the contemporary world. Significant global scientific and technological progress has been made in the last two decades in this area, with extraordinary breakthroughs in human and veterinary vaccines. These advances, resulting from new paradigms in Vaccinology 4.0, such as genomic vaccines, mRNA technology, and plant expression of vaccine antigens, are evidenced by the unprecedented speed in vaccine development initiatives and international collaborations during COVID-19 pandemic, with several clinical trials just 9 months since the emergence of the outbreak in Wuhan, China. Notwithstanding this accelerated pace of vaccine development, many gaps and challenges persist in global vaccine development and STI governance for COVID-19, including the need to protect against recent concerning new viral variants in the UK, South Africa, and Brazil. In this article, we examine four major issues that could impact on global vaccine availability and sustainability in the post-COVID-19 scenario: (I) leading SARS-CoV-2 vaccines; (II) patent protection, global patent assignees for vaccines against pandemic diseases (COVID-19) or potentially pandemic diseases (SARS, MERS); (III) patent assignees for SARS, MERS, and COVID-19, clinical trials, local capacity for production, and for development of COVID-19 vaccines patents for COVID-19, SARS, and MERS for three agro-based emerging countries (India, South Africa, and Brazil) are described for the period 2010-2020; and (IV) the role of vaccines in the circular bioeconomy model, as a key global resource-saving strategy, preventing expenditures with COVID-19 hospitalizations and life-saving medical devices and equipments, reducing high-risk biological hospital waste, and contributing to meet sustainability and circular economy goals. Finally, in the "Future Scenarios" section, we provide considerations on post-COVID vaccine scenarios. These future scenarios, supported by vaccine patent information, indicate that vaccines are a crucial component of global pandemic preparedness, and thus an exponential increase in funding vaccine research, development, innovation, and production should be an utmost priority.

\section{Conceptual Framework: Vaccines in Circular Bioeconomy Model}

Vaccines have emerged in the Vaccinology 4.0 scenario as the future of medicine, expected to increasingly substitute high-cost and resource-consuming curative interventions and consequently, to drastically reduce the high-risk biological waste from these interventions in hospitals and healthcare units, a major environmental and social concern, recently severely aggravated in COVID-19 pandemic. For these reasons, vaccines are key for pandemic preparedness in the direction of a circular bioeconomy model. The urgent need for a transition in the health sector from a linear bioeconomy model ("take, make, dispose") to a circular bioeconomy model ("renew, remake, share") is becoming increasingly evident. Notwithstanding, although this economic paradigm change is clear, with circular economy replacing the linear economy, in the direction of a resource-saving and sustainable world, the huge contribution that vaccines can provide to the circular bioeconomy model has not been discussed in 
the so far scarce literature on circular economy and health [1], focused on the potential health impacts of circular economy and not on the extraordinary contributions that innovative health products, such as vaccines or preventive antiviral drugs, could provide in a circular bioeconomy model. Vaccines are definitely a key resource-efficient strategy for circular economy, as indicated in Fig. 1, and have already contributed to a sharp reduction in interventions and related direct and indirect expenditures from COVID-19 hospitalizations [2], minimizing the environmental and social impacts of high-risk biological hospital waste, contributing to global sustainability and emerging as a crucial circular economy component.

\section{Methodology}

Patent information for COVID-19 vaccines and vaccines for other potentially pandemic diseases (SARS and MERS) is presented for the period 2010-2020, in a search from Derwent Innovation database and from Espacenet database. Information is also provided for the different phases of vaccine clinical trials, from the registry ClinicalTrials.gov. We also provide information for vaccine patents and clinical trials in three emerging agro-based countries (India, Brazil, and South Africa) and an overview of their relative participation in BRICS countries, in a search from abovementioned databases.

\section{COVID-19 Vaccines: State-of-the Art}

Vaccines usually require decades of research and testing before reaching clinical trials, but in 2020, in an unprecedented speed and extraordinary international collaboration to respond to the pandemic, scientists succeeded to develop and produce safe and effective COVID-19 vaccines in just 9 months after the emergence of the pandemic in Wuhan, China. Researchers are currently testing 67 vaccines in clinical trials on humans, and 20 have reached the final

\section{Vaccines: Circular Bioeconomy Model}

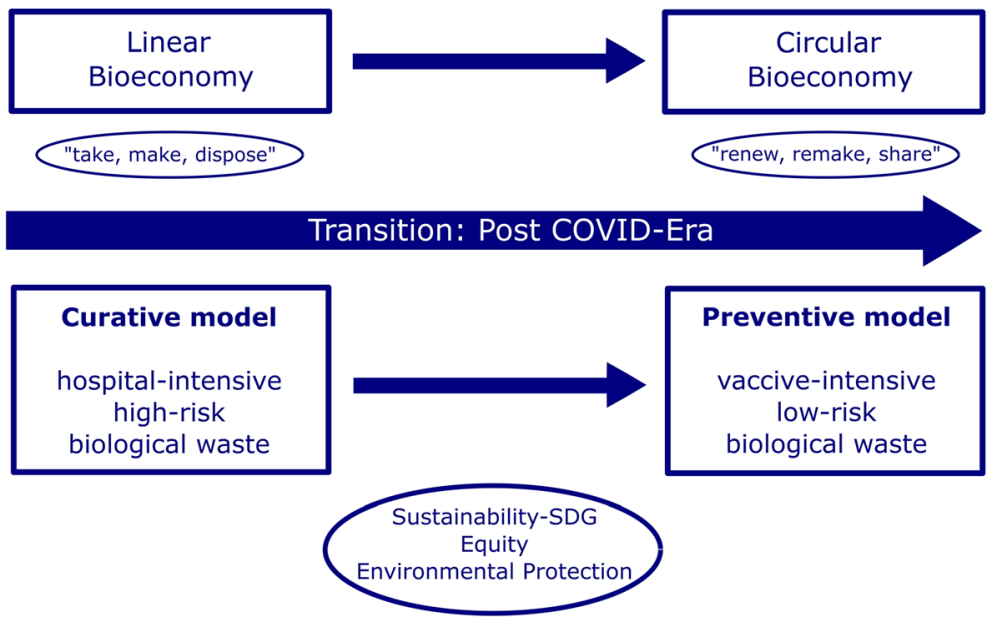

Fig. 1 Vaccines in circular bioeconomy model: post- COVID-19 era. Elaborated by the authors 
stages of testing [3, 4]. In Table 1, we present the leading SARS vaccines according to technology, efficacy, phase, and regulatory status.

The innovative COVID-19 vaccines presented in Table 1 are in fact the result of a cumulative process starting two decades ago with novel vaccine platforms and new technologies, such as mRNA, modRNA, engineered viral vectors, and other previous novel vaccine strategies against other coronavirus vaccines such as SARS and MERS. The rationale is that, from a cumulative knowledge perspective, these previous breakthroughs were crucial for the accelerated speed of just 9 months from the emergence of the pandemic in Wuhan, China, to produce safe and effective COVID-19 vaccines. Concerning SARS and MERS vaccines, this cumulative process is explained by the structural similarity among the viral proteins responsible to the viral activity (entry and replication into host cells) [9].

In addition, it should be noted that in spite of these breakthroughs in COVID-19 vaccine development, significant knowledge gaps persist, related to immunity and protection. It is not clear yet the extent of duration of immunity and protective immune responses. There are evidence suggesting that adaptive immune responses elicited by SARS-CoV-2 infection might protect against reinfection [10]. Results from seasonal coronaviruses infection [11] and current experience with SARS-CoV-2 suggest that immunity to natural infection might wane over time ("waning immunity") and reinfection has been reported [12]. There is the possibility that

Table 1 Leading SARS-CoV-2 vaccines: approved and/or authorized for emergency use ${ }^{(1)}$

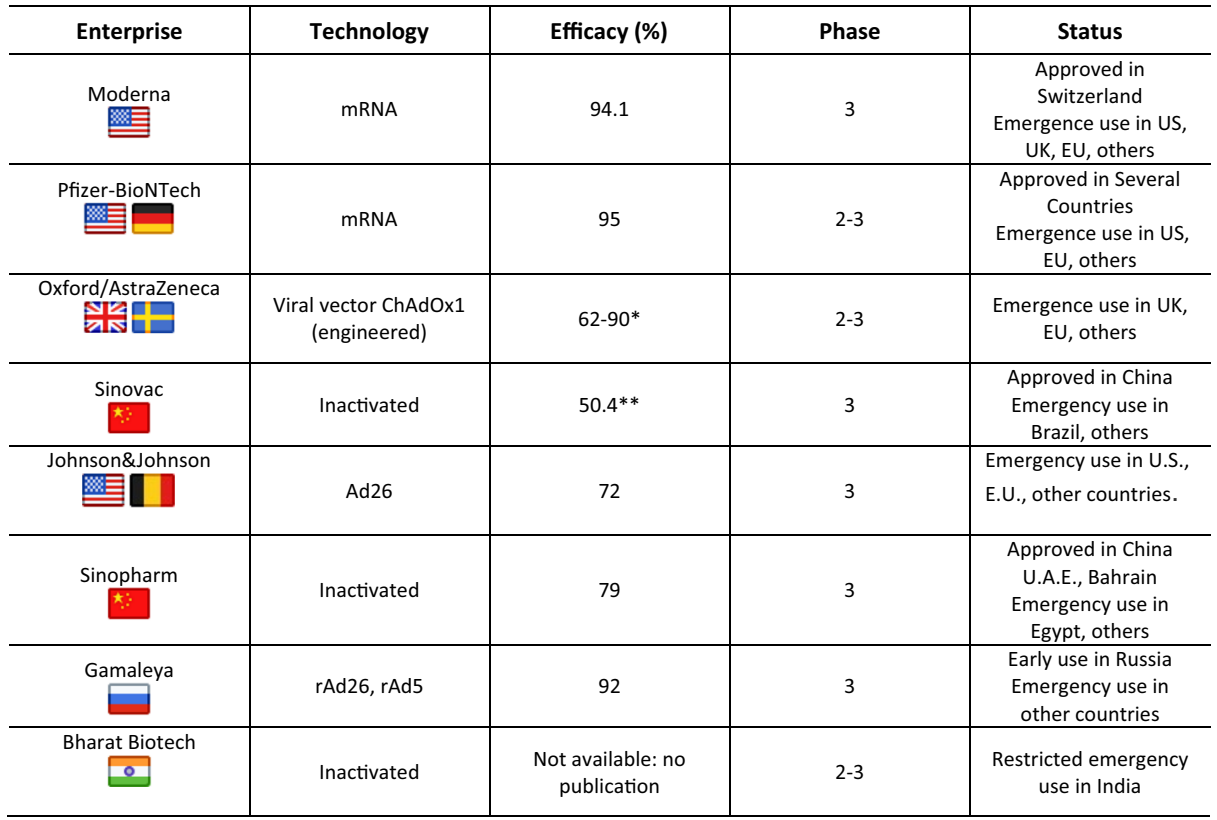

*62\% at first half dose, $90 \%$ at second dose

**Different efficacy results from trials in different countries: Brazil 50.4\%, Turkey $91.2 \%$, and Indonesia $65.3 \%$. For Turkey and Indonesia provided interim results from late stage trials. Publications and additional data needed to clarify efficacy rates

(1)As of February 20, 2021

Sources: Baden et al. [5], Polack et al. [6], Logunov et al. [7], WHO [3], Voysey et al. [8]

Elaborated by the authors 
additional booster doses might be necessary to extend the duration of protection. It is also unclear whether previously infected persons would benefit from vaccination, although vaccination against SARS-CoV-2 is recommended irrespective of infection status [13].

In the "Leading Global Patent Assignees: Vaccines for COVID-19, SARS, and MERS" section, a search in patent documents is provided, describing these preceding breakthroughs and novel vaccine platforms.

\section{Leading Global Patent Assignees: Vaccines for COVID-19, SARS, and MERS}

In this section, we examine, for the period 2010-2020, patent data from leading global patent assignees for vaccines against pandemic (COVID-19) or potentially pandemic (SARS and MERS). To define the universe of research, our first search was directed to identify, from a global perspective, where the vaccines and related technologies for COVID-19, SARS, and MERS disease had been developed ${ }^{1}$. A total of 1235 individual records were recovered, with the USA and China as top assignees, as indicated in Fig. 2.

The top assignees are shown in Fig. 3. From the graphs' analysis, in spite of CureVac leading position, no company stood out for numbers of applications.

A further novel finding scenario was observed for the BRICS' countries (Brazil, Russia Federation, India, China, and South Africa) (Fig. 4). Here the top assignee is China. India and Russia Federation have a small representation in the rank. Brazil and South Africa had not applied any priority document for vaccines for SARS, MERS, or COVID-19 according to the strategy $\operatorname{search}^{2}(\mathrm{~A})$.

\section{India, South Africa, and Brazil: Patent Assignees for SARS, MERS, and COVID-19}

In order to describe the specific role of the three agro-based emerging countries, India, South Africa, and Brazil, in vaccine development scenario, a new strategy search was applied ${ }^{2}(B)$. For all countries, a few vaccine patent documents for COVID-19 were observed (considering both criteria, country's priority or application of global assignees in the country, which was expected due to the patent secrecy's period). The results are described below (Table 2).

EPO European Patent Office

(*) 1 document: Canada and Netherlands

\footnotetext{
${ }^{1}$ The search was done in Derwent Innovation Database (Clarivate Analytics) using terms for Respiratory Syndromes associated to coronavirus (SARS OR "SEVERE ACUTE RESPIRATORY SYNDROME" OR MERS OR "MIDDLE EAST RESPIRATORY SYNDROME" OR COVID* OR "SARS-CoV-2" OR "WUHAN VIRUS" OR "2019 nCoV" OR "SARS-2") associated to the word vaccine or vaccination in the search field "Title/abstracts/claims." The strategy search used the following International Patent Classification (IPC): A61k0039 (IPC group: for medical preparations containing antigens or antibodies) or A61k0039215 (IPC subgroup: vaccine against coronavirus (European Patent Office-EPO).

${ }^{2}$ The search was done in Derwent Innovation Database (Clarivate Analytics) using terms for Respiratory Syndromes associated to coronavirus (SARS OR "SEVERE ACUTE RESPIRATORY SYNDROME" OR MERS OR "MIDDLE EAST RESPIRATORY SYNDROME" OR COVID* OR "SARS-CoV-2" OR "WUHAN VIRUS" OR "2019 nCoV" OR "SARS-2") associated to the word vaccine or vaccination in the search field "Title/abstracts/claims." The strategy search used the following International Patent Classification (IPC): A61k0039 (IPC group: for medical preparations containing antigens or antibodies) or A61k0039215 (IPC subgroup: vaccine against coronavirus) (European Patent Office-EPO). A. The "priority country/region earliest" are from BRICS (Brazil, Russia, India, China, and South Africa (total: 111 DWPI families); B. The priority countries were IN (India), ZA (South Africa), and BR (Brazil) separately.
} 


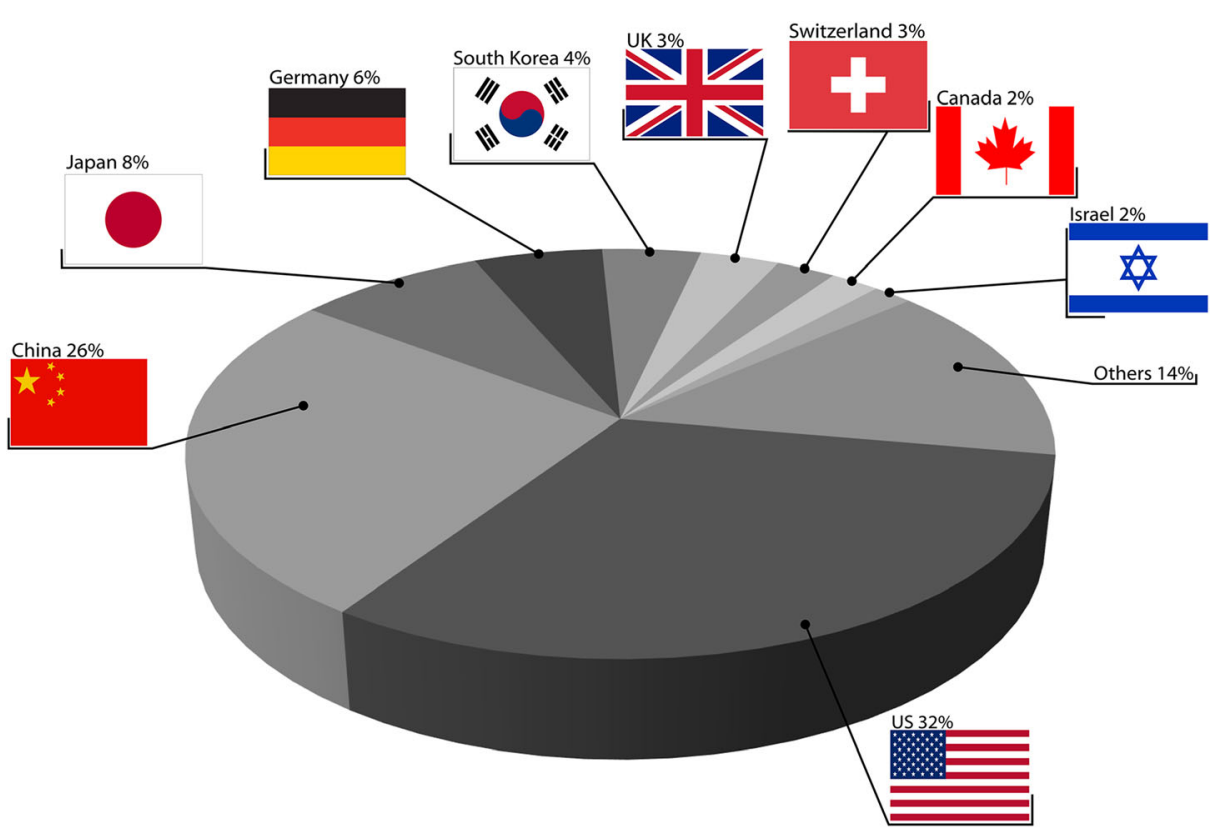

Fig. 2 Patent assignee countries for vaccines for SARS, MERS, and COVID-19 (period: 2010 and 2020). Elaborated by the authors. Source: Derwent Innovation (Clarivate Analytics)

\section{India: Vaccine Patent Assignees for SARS, MERS, and COVID-19}

The search recovered only 6 Indian patent documents (Indian companies), most of them from 2020. There was not a leading Indian vaccine applicant among them. The Patent Document ${ }^{3}-$ PN: IN202011016574A (Mangalmay Institute of Engineering and Technology, India) [14] discloses about a novelty: an isolated human coronavirus which causes SARS and comprises a nucleotide sequence/acid molecule which under stringent condition can hybridize. This invention is "related to Computer Engineering and newly isolated human coronavirus" with scientific research and clinical applications including the development of vaccines.

The invention from Sinha Kanishk (PN: IN202031014832A (individual's application) [15] "Vaccine for Novel Coronavirus" is related to advanced immunotherapy to treat novel coronavirus patients. Its composition comprises "cytokine-expressing, proliferation incompetent, whole novel coronavirus cells, anti-programmed death 1 (PD-1) antibody, and toll like receptor (TLR) agonist." Another invention related to composition of infectious mRNA, RNA, and RNA of SARS coronavirus, SARS coronavirus replicon particles, recombinant ones, and methods of making and using the compositions. It is related to Computer Engineering and Medical Science. The composition expresses heterologous nucleic acids and can be used as vaccines and/or immunogens (PN: IN202041016724A-individual's application) [16].

The document PN: IN202011018851A (individual's application) [17] and PN: IN202011024811A (individual's application) [18] described a diagnostic kit reagent related to proteins and nucleic acids from COVID-19 and to vaccine formulations which comprises respiratory virus antigens (one or more) and COVID-19 virus antigens (one or more).

\footnotetext{
${ }^{3}$ In the present research, the term "Patent Number or PN" refers to the Publication Number of the applied patent.
} 


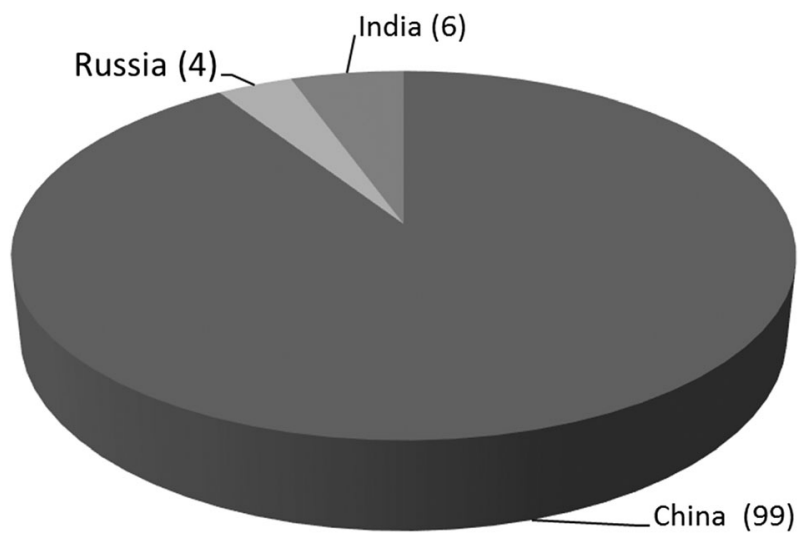

Fig. 3 Top patent assignees for vaccines for SARS, MERS, and COVID-19 (period: 2010 and 2020). Elaborated by the authors. Source: Derwent Innovation (Clarivate Analytics)

The results highlighted that little was recovered about the COVID-19's vaccine. A complementary search was done ${ }^{4}$ to give clear better results about the subject matter.

How it was expected (due to patent document's secrecy period), only one document from Indian individual applicants was recovered: PN: IN202021024459A [19], which is about a high immunogenic and stable vaccine with the inactivated virus from partially attenuated and/ or normal strain.

Foreign Assignees in India We identified 18 applicants/assignees (companies/institutions/ countries) which applied in India ( 8 from the USA, 8 from Europe, and 2 from Asia). The main applicant was CureVac GMBH from Germany (with 4 documents).

North America The patent document from Novavax Inc. - US (PN: IN201617013371A) [20] discloses about nanotechnology: Immunogenic compositions which comprises nanoparticles containing MERS virus proteins. These particles are in polymer compositions and structures. These compositions can be used as vaccines to induce neutralizing antibodies against the virus. One intriguing finding is that an immunogenic composition for inducing immune response against MERS-CoV in subjects is also cost-effective, with an excellent biological stability (PN: IN201617021769A) (the Trustees of the University of Pennsylvania, USA) [21]. Another promising finding is that the Regeneron Pharmaceuticals, Inc., USA applied (PN: IN201647039008A) [22] an invention which provides monoclonal antibodies to bind MERS-CoV spike protein (Regeneron Pharmaceuticals, Inc., USA). Moreover, a novelty in polymeric nanoparticles was applied by President and Fellows of Harvard College/ Massachusetts Institute of Technology/The Brigham and Women's Hospital, Inc., USA (PN: IN201503426P2) [23] which stimulates mucosal immune response by the administration of an inactivated pathogen (preferably bacteria) or virus like SARS coronavirus or common cold influenza (President and Fellows of Harvard College; Massachusetts Institute of Technology; The Brigham and Women's Hospital, Inc.). Our results casts a new light on immunogenic compositions: The use of a silicified virus/silicified virus, including SARS, MERS, and

\footnotetext{
${ }^{4}$ Espacenet and Derwent Innovation Index Databases. Strategy Search: Terms: COVID-19 or COVID or "Coronavirus Disease-19" or "SARS-COV-2" or nCoV or "novel coronavirus" or "SARS2" or "Wuhan coronavirus") and vaccine, without a specific period. The research was conducted on January 25, 2021.
} 


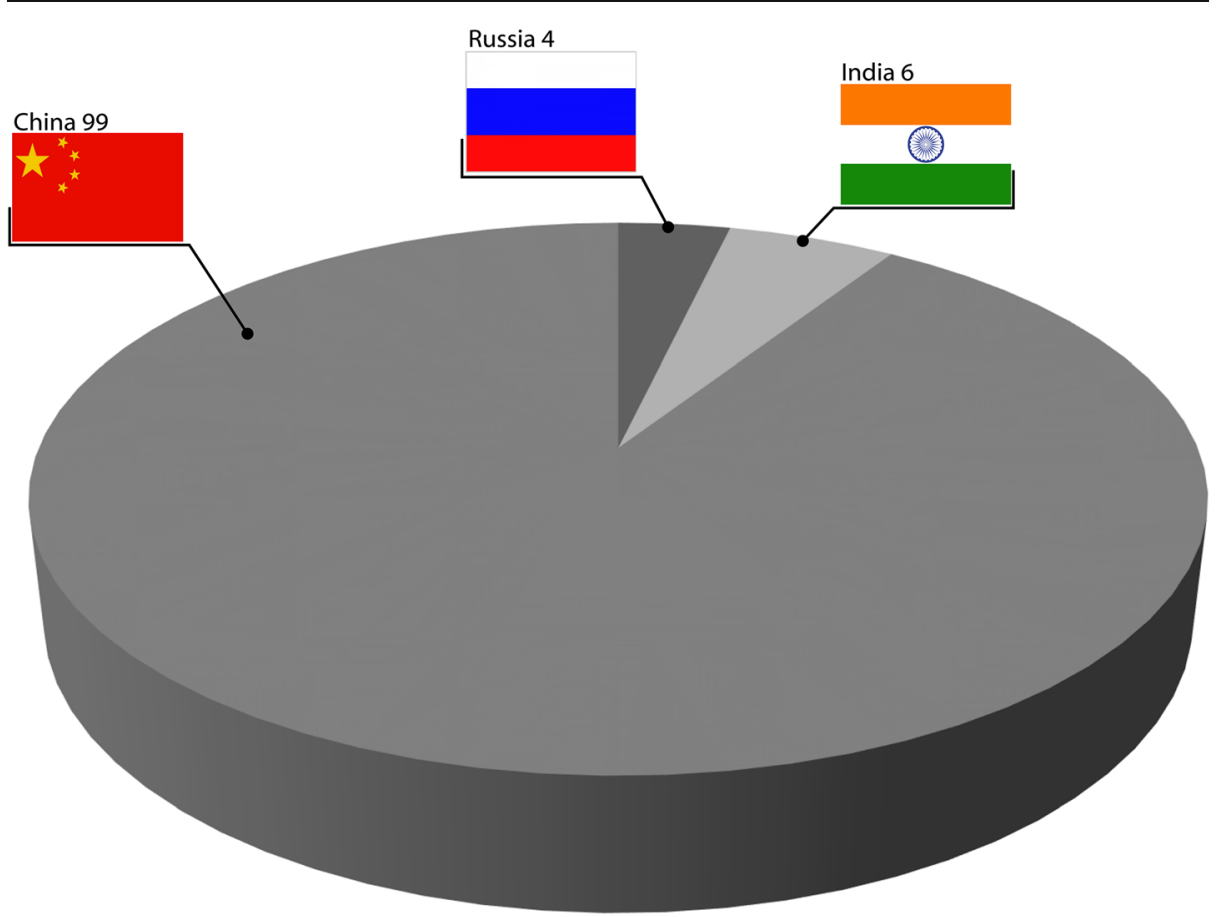

Fig. 4 BRICS' patent assignees for vaccine for SARS, MERS, and COVID-19 (period: 2010 and 2020). Elaborated by the authors. Source: Derwent Innovation (Clarivate Analytics)

influenza virus to induce (PN: IN201506559P1) [24] a virus-specific immune response which are useful as vaccines (Portland State University; Providence Health \& Services Oregon, USA). Moreover, an applied biotechnology method (PN: IN201510078P1-University of Iowa Research Foundation; The University of Kansas, USA): a chimeric virus was isolated and it comprises "bocavirus capsid protein and recombinant adeno-associated viral (AAV) genome." Virus gene product proteins from SARS or influenza were claimed [25].

The document recovered PN: IN201305009P4 [26] (Medicago Inc., Canada) was aligned with applied biotechnology: it is a method to introduce the nucleic acid, expressed in the plant. Some virus fragments or virus trimeric surface protein was chosen. Among them, SARS virus,

Table 2 Initial results of applicant documents for the priority countries: India, South Africa, and Brazil according to strategy search

\begin{tabular}{lllll} 
Countries & Origin: priority country & \multicolumn{2}{l}{\begin{tabular}{l} 
Number of applicant documents for SARS, MERS, and COVID-19 \\
\cline { 3 - 5 }
\end{tabular}} & $\begin{array}{l}\text { Origin: countries with applications in India, South Africa, } \\
\text { and Brazil (priority countries) }\end{array}$ \\
\hline Groups & & North America & Europe & Asia \\
\hline India & 6 & 8 & 8 & 2 \\
South Africa & 0 & $3(*)$ & 1 & - \\
Brazil & 0 & 6 & 4 & 2 \\
\hline
\end{tabular}

Elaborated by the authors

Source: Derwent Innovation (Clarivate Analytics) 
influenza virus, measles virus, etc. That is a production of a virus like particle (VLP) in a plant to prevent or /and treat (vaccine) these viral infections. The document from Folia Biotech Inc., Canada (PN: IN201310534P1) [27] is also an example of VLPs in vitro. It comprises "combining recombinant Potexvirus coat protein and single stranded RNA, and treating the VLPs with nuclease to remove any RNA protruding from the particles" to be used in combination with antigens (from virus like SARS) as a vaccine.

Europe From Novartis AG from Switzerland (PN: IN201203534P2) [28] was applied an invention of methods to prepare squalene which can be used in a vaccine composition for diseases like SARS coronavirus and others (HIV, varicela, human papillomavirus, etc.).

The document (PN: IN291696B-CureVac AG from Germany) [29] is an immunostimulatory composition that may be used like a vaccine or a pharmaceutical composition from CureVac AG. It can be used to treat SARS, influenza, autoimmune diseases, tumor diseases, and others.

The document (PN: IN201404812P1) [30] (CureVac GMBH from Germany) reinforces the general belief that the use of the nucleic acid to increase the expression of a pathogenic antigen which was encoded. About this invention from CureVac GMBH, the nucleic acid "comprises coding for a histone stem-loop and a poly(A) sequence or a polyadenylation signal" for genetic vaccination for prophylactic treatment or therapeutic use of infectious diseases, like SARS or influenza, for example. A further novel finding is about vaccine formulations. A polyples formulation which can be used to deliver RNA to a target organ/cell after intramuscular administration particularly (PN: IN202047028961A-BioNTech RNA Pharmaceuticals GmbH and TRONTranslationale Onkologie an der Universitätsmedizin der Johannes Gutenberg-Universität Mainz $\mathrm{gGmbH}$. Both of them from Germany) is used against the antigen or epitope of infectious diseases like SARS, influenza, etc. [31]. A further novel finding is the new carbohydrate-glycolipid conjugates (PN: IN201408326P1-Max-Planck-Gesellschaft zur Förderung der Wissenschaften e. V. from Germany and Universitätsspital Basel from Switzerland) That is used to prepare vaccines against infectious diseases [32]. The saccharide antigen can be from a viral glycoprotein of SARS, influenza viral, etc. And a RNA vaccine (PN: IN201506225P1-CureVac GMBH, Germany) with an "open reading frame coding for antigen and composition with a programmed death-1 pathway inhibitor" for treatment and prevention of cancer or infectious diseases, like SARS and influenza [33]. An intranasal immunization (compositions and methods) with recombinant Modified Vaccinia virus Ankara was claimed using the nucleic acid which encodes the antigen for the induction of an immune response. The antigens can be a tumor-associated antigen, bacteria, parasite, fungus, or virus (e.g., SARS, influenza, or parainfluenza virus) and flagellin (PN: IN201717009706ABavarian Nordic A/S, Denmark) [34]. A RNA composition (PN: IN201817022402A) was applied by CureVac AG (Germany) used as vaccine, gene-therapeutic agent, or immunotherapeutic agent. The selected pathogen can be a virus like SARS [35].

Asia The document applied by the University of Tokushima, Japan (PN: IN201207596P1) [36] is a mucosal vaccine which comprises the drug and antigen vehicle, carboxyvinyl polymer, and the antigenic protein for induction of immune response against many virus, including SARS virus, influenza virus, yellow fever virus, etc. Indeed, the method, the mutated influenza virus, attenuated, and the live vaccine from the document PN: IN201817042073AEmerging Viral Vaccine Limited and Versitech Limited. Both from China) comprise "an insertion of gene encoding for an exogenous antigen" which can be an SARS/MERS virus or influenza virus, for example [37]. 


\section{South Africa: Vaccine Patent Assignees for SARS, MERS, and COVID-19}

According to our strategy search, no document was recovered for South Africa as priority country.

Foreign Assignees in South Africa Our results demonstrated that there are a few number of patent documents (four) from other country. The main applicants were Medicago Inc. (from Canada), Novartis AG (Switzerland), Irdeto BV (Netherlands), Univ Iowa Res Found, and Univ Kansas (both of them from US). Three documents were applied in 2010 and only one in 2013.

North America A "new isolated chimeric virus comprises bocavirus capsid protein and recombinant adeno-associated viral genome" (PN: ZA201507946B-Univ Iowa Res Found; Univ Kansas. Both from US). The gene product includes a viral antigen (from SARS virus protein, e.g.) which is a prophylactic gene product [38].

In addition, production of virus like particle to treat and prevent viral infections, including SARS, influenza, rabies, etc. (PN: ZA201305407B-Medicago Inc., Canada; ZA201400166B (Medicago Inc., Canada; Irdeto BV - Netherlands) [39, 40].

Europe A vaccine comprising squalene as adjuvant (PN: ZA201208381B-Novartis AG, Switzerland) against SARS and other virus like influenza virus, HIV, etc [41].

\section{Brazil: Vaccines Patent Assignees for SARS, MERS, and COVID-19}

No Brazilian documents were recovered according to our search strategy.

Foreign Assignees in Brazil Only a few documents have shown the applications in Brazil: 12 documents. None of them was recovered to Brazil as priority country. Most documents were applied in 2013 (four) and the main assignee was CureVac GMBH (Germany).

North America A new live and attenuated coronavirus (SARS, MERS, etc.) which has excellent stability to prevent diseases was claimed by Loyola University Chicago from the USA. The coronavirus (mutation of wild-type) has amino acid changes (PN: BR112019018251A2) [42].

From Portland State University, USA (PN: BR112015017966A2) [43]: An immunogenic composition to induce a virus-specific immune response and to raise the "virus specific cellmediated immune response" against SARS, MERS, etc.

BR112015021970A2 [44] from President and Fellows of Harvard College, USA, is about a composition which includes an adjuvant loaded polymeric nanoparticles - attached to the inactivated antigen to promote the stimulation of mucosal response against SARS, common cold-influenza, dengue fever, etc. Moreover, a MERS-CoV nanoparticle where it is possible the administration of "the purified high affinity antibody to a human subject" from Novavax Inc., US (PN: BR112016006122A2) [45].

The technology to produce human monoclonal antibodies (recombinant antibodies) from Regeneron Pharmaceuticals, Inc., USA (PN: BR112016025009A2) to prevent MERS infection. Moreover, MERS-CoV spike proteins bind to "isolated recombinant antibody or its antigen-binding fragment" [46]. 
Production of VLP in a plant was also claimed, by the introduction of the nucleic acid in a plant. The composition can be used to treat/prevent viral infection, including SARS, smallbox (PN: BR112013016185A2-Medicago Inc., Canada) [47].

Europe A method to prepare a squalene composition for vaccines preparations (adjuvant) is new. The composition, which comprises parvalbumin and proteins, uses antigens for the development of the vaccine against SARS, Influenza, HIV, etc. (PN: BR112012028711A2Novartis AG, Switzerland) [48].

A protein/peptide which increases expression to treat infectious diseases from the nucleic acid sequence (pathogenic antigen for SARS, HIV, dengue, etc) from CureVac GMBH, Germany (PN: BR112014016361A2) [49].

From Universitätsspital Basel, Switzerland (PN: BR112014023193A2) [50], an active agent raises the immune response against infectious diseases (e.g., SARS and influenza). Bacterial capsular saccharide antigen or other antigens (e.g., viral glycoproteins are used).

A RNA vaccine which comprises a códon-optimized region and (at least) one open reading frame (ORF) to treat/prevent disease like cancer and infectious ones: SARS, influenza, etc. (PN: BR112015018989A2-CureVac GMBH, Germany) [51].

Asia From the University of Tokushima, Japan, a new vaccine of mucous membrane was applied. A mucosal vaccine (antigen and drug vehicle) can be used to induce immune response against antigens as SARS, influenza virus, dengue virus, etc. (PN: BR112012022059A2) [52].

The mutant virus (e.g., SARS and I was applied by Peking University from China can be used as an attenuated vaccine. The mutated virus is prepared by (e.g., "expressing mutated nucleic acid expression vector" (PN: BR112018013168A2) [53].

\section{India, South Africa, and Brazil: Clinical Trials for COVID-19 Vaccines}

Brazil, India, and South Africa play an important role as sites for collaboration in international clinical trials for COVID-19 vaccines. The significant investment by pharmaceutical companies in clinical trials in these three countries contrasts with limited investments in technological transfer agreements and strengthening local capacity for technological development in these countries.

Clinical Trials for COVID-19 vaccines are illustrated in Tables 3 (India), 4 (South Africa), 5 (Brazil), and 6 (multi-country). These tables present the clinical trial phase, status, and sponsor's descriptions. The search was conducted from the base clinicaltrials.gov and a strategy search ${ }^{5}$. We also searched the COVID-19, living NMA initiative provided by WHO that collected 164 RCTs and 48 non-randomized studies of vaccines for COVID-19 from the ICTRP. Our results cast a new light on the participation of the referred countries in vaccine's development (Tables 4, 5, and 6).

\section{Development and Production of COVID-19 Vaccines: India, South Africa, and Brazil}

Concerning the development and production of COVID-19 vaccines, Table 7 presents the partnerships with leading enterprises made by institutions in India, South Africa, and Brazil, for

\footnotetext{
${ }^{5}$ Database: Clinical Trials. The search used the terms "COVID-19, COVID, SARS-CoV-2, Severe Acute Respiratory Syndrome Coronavirus 2" (January 22, 2021)
} 
Table 3 India clinical trials for COVID-19 vaccines-country-based trials as of February 18, 2021

Title Phases Status Sponsor

An Efficacy and Safety Clinical Trial of an
$\begin{aligned} & \text { Investigational COVID-19 Vaccine } \\ & \text { (BBV152) in Adult Volunters }\end{aligned}$$\quad \mathrm{R} \quad \begin{gathered}\text { Bharat Biotech International Limited|Indian } \\ \text { Council of Medical Research|Iqvia Pty Ltd }\end{gathered}$

152) in Adult Volunteer

BCG Vaccine in Reducing Morbidity and

Mortality in Elderly Individuals in COVID-19 Hotspots

$3 \quad \mathrm{R}$

Tuberculosis Research Centre,

India|ICMR-National Institute for Research

in Tuberculosis, Chennai, Tamil Nadu|All

India Institute of Medical Sciences, New

Delhi|National Institute for Research in

Environmental Health, Bhopal, Madhya

Pradesh|National Institute of Occupational

Health, Ahmedabad, Gujarat|King Edward

Memorial Hospital|National Institute for

Implementation Research on

Non-Communicable Disease

Clinical Trial to Assess Safety and

Immunogenicity of Gam-COVID-Vac

Combined Vector Vaccine for Severe Acute

Respiratory Syndrome Coronavirus 2

(SARS-Đ;ov-2) Infection -

Gamaleya-Sputinik Vaccine

Whole-Virion Inactivated SARS-CoV-2 Vac- 1/2 A cine (BBV152) for COVID-19 in Healthy

Volunteers

Safety and Immunogenicity of an Intranasal SARS-CoV-2 Vaccine (BBV154) for COVID-19

Novel Corona Virus-2019-nCov vaccine by intradermal route in healthy subjects.

A Phase 2/3, Observer-Blind, Randomized, Controlled Study to Determine the Safety and Immunogenicity of Covishield (COVID-19 Vaccine) in Healthy Indian Adults

Whole-Virion Inactivated SARS-CoV-2 Vaccine (BBV152) in Healthy Volunteers

A Phase 1, Followed by a Phase 2, vaccine given Randomly in subjects in different sites to Evaluate the Safety, side effects, and resistance of the Virus Vaccine, BBV152D Administered between the layers of the skin (intradermal) in Healthy Volunteers

Biological E's novel Covid-19 vaccine of SARS-CoV-2 for protection against Covid-19 disease.

Novel Corona Virus-2019-nCov vaccine by intradermal route in healthy subjects.

\section{2/3 R Dr. Reddy's Laboratories Limited|Gamaleya \\ Research Institute of Epidemiology and Microbiology, Health Ministry of the Russian Federation|RDIF (Russian Direct Investment Fund)|CRO: JSS Medical Research India Pvt. Ltd. \\ Bharat Biotech International Limited|Indian Council of Medical Research}

N Bharat Biotech International Limited

$1 / 2$ A Cadila Healthcare Ltd

$2 / 3$ A Serum Institute of India Private Limited Indian Council of Medical Research ICMR

$\begin{array}{lll}1 / 2 & \text { A } & \text { Bharat Biotech International Limited } \\ 1 / 2 & \text { A } & \text { Bharat Biotech International limited }\end{array}$

$1 / 2$ A Biological ELimited

3 R Cadila Healthcare Ltd

$R$ recruiting, $N$ not yet recruiting, $A$ active, not recruiting

Source: clinicaltrials.gov Database and COVID-19-living NMA initiative

Elaborated by the authors

vaccine development based on data recovered from the Chemical Business NewsBase (CBNB). Table 8 presents local capacity for production in these countries. These Tables evidence the leading role of India in technological capacity for development and production of COVID-19 
Table 4 South Africa clinical trials for COVID-19 vaccines-country-based trials as of February 18, 2021

\begin{tabular}{lllll}
\hline Title & Phases & Status & Sponsor \\
\hline $\begin{array}{l}\text { A Study Looking at the Effectiveness and } \\
\text { Safety of a COVID-19 Vaccine in South } \\
\text { African Adults }\end{array}$ & 2 & R & & Novavax|Bill and Melinda Gates Foundation \\
$\begin{array}{l}\text { COVID-19 Vaccine (ChAdOx1 nCoV-19) } \\
\text { Trial in South African Adults With and } \\
\text { Without HIV-infection }\end{array}$ & $1 / 2$ & A & $\begin{array}{l}\text { University of Oxford|Medical Research } \\
\text { Council, South Africa|Bill and Melinda } \\
\text { Gates Foundation|Wits Health Consortium } \\
\text { (Pty) Ltd|University of Witwatersrand, South } \\
\text { Africa }\end{array}$ \\
\hline
\end{tabular}

$R$ recruiting, $N$ not yet recruiting, $A$ active, not recruiting

Source: clinicaltrials.gov Database and COVID-19-living NMA initiative

Elaborated by the authors

vaccines, leaded by the Serum Institute of India. In second position, Brazil with two technological transfer agreements from Oxford/AstraZeneca with Oswaldo Cruz Foundation/Bio-Manguinhos and from SINOVAC with Butantan Institute and local capacity for production in both institutions.

Table 5 Brazil clinical trials for COVID-19 vaccines-country-based trials as of February 18, 2021

\begin{tabular}{|c|c|c|c|}
\hline Title & Phases & Status & Sponsor \\
\hline $\begin{array}{l}\text { A Study of a Candidate COVID-19 Vaccine } \\
\text { (COV003) }\end{array}$ & 3 & $\mathrm{R}$ & University of Oxford \\
\hline $\begin{array}{l}\text { Clinical Trial of Efficacy and Safety of Sinovac's } \\
\text { Adsorbed COVID-19 (Inactivated) Vaccine in } \\
\text { Healthcare Professionals }\end{array}$ & 3 & $\mathrm{R}$ & $\begin{array}{l}\text { Butantan Institute|Sinovac Life Sciences } \\
\text { Co., Ltd. }\end{array}$ \\
\hline $\begin{array}{l}\text { COVID-19: BCG As Therapeutic Vaccine, } \\
\text { Transmission Limitation, and Immunoglobulin } \\
\text { Enhancement }\end{array}$ & 4 & $\mathrm{R}$ & $\begin{array}{l}\text { University of Campinas, Brazil| } \\
\text { Conselho Nacional de Desenvolvimento } \\
\text { Científico e Tecnológico| } \\
\text { Instituto de Infectologia Emílio Ribas| } \\
\text { Pontifícia Universidade Católica de } \\
\text { Campinas, PUC-Campinas| } \\
\text { Faculty of Medicine of Ribeirão Preto } \\
\text { (FMRP-USP)| } \\
\text { Faculdade de Medicina de Botucatu, } \\
\text { UNESP, Botucatu, Brasil| } \\
\text { Federal University of São Paulo| } \\
\text { State Hospital Dr. Leandro Franceschini, } \\
\text { Sumaré, Unicamp| } \\
\text { Paulinia Municipal Hospital }\end{array}$ \\
\hline $\begin{array}{l}\text { Use of BCG Vaccine as a Preventive Measure for } \\
\text { COVID-19 in Health Care Workers }\end{array}$ & 2 & $\mathrm{R}$ & $\begin{array}{l}\text { Universidade Federal do Rio de } \\
\text { Janeiro|Ministry of Science and } \\
\text { Technology, Brazil }\end{array}$ \\
\hline $\begin{array}{l}\text { A phase III study to investigate a vaccine against } \\
\text { COVID-19 }\end{array}$ & 3 & A & University of Oxford \\
\hline $\begin{array}{l}\text { Clinical Trial of Efficacy and Safety of Sinovac's } \\
\text { Adsorbed COVID-19 (Inactivated) Vaccine in } \\
\text { Healthcare Professionals (PROFISCOV) }\end{array}$ & 3 & A & $\begin{array}{l}\text { Butantan Institute; Sinovac Life Sciences } \\
\text { Co., Ltd. }\end{array}$ \\
\hline
\end{tabular}

$R$ recruiting, $N$ not yet recruiting, $A$ active, not recruiting

Source: clinicaltrials.gov Database and COVID-19-living NMA initiative

Elaborated by the authors 
Table 6 Multi-country clinical trials for COVID-19 vaccines-country-based trials as of January 22, 2021

\begin{tabular}{|c|c|c|c|c|}
\hline Title & Phases & Status & Sponsor & Countries \\
\hline $\begin{array}{l}\text { The Efficacy, Safety and } \\
\text { Immunogenicity Study of } \\
\text { Inactivated SARS-CoV-2 } \\
\text { Vaccine for Preventing } \\
\text { Against COVID-19 }\end{array}$ & 3 & $\mathrm{~N}$ & $\begin{array}{l}\text { Chinese Academy of Medical } \\
\text { Sciences }\end{array}$ & Brazil and Malaysia \\
\hline $\begin{array}{l}\text { A Controlled Phase } 2 / 3 \text { Study } \\
\text { of Adjuvanted Recombi- } \\
\text { nant SARS-CoV-2 Trimeric } \\
\text { S-protein Vaccine } \\
\text { (SCB-2019) for the Preven- } \\
\text { tion of COVID-19 }\end{array}$ & $2 / 3$ & $\mathrm{~N}$ & $\begin{array}{l}\text { Clover Biopharmaceuticals } \\
\text { AUS Pty Ltd|The Coalition } \\
\text { for Epidemic Preparedness } \\
\text { Innovations|International } \\
\text { Vaccine Institute }\end{array}$ & $\begin{array}{l}\text { Belgium, Brazil, Colombia, } \\
\text { Dominican Republic, } \\
\text { Germany, Nepal, Panama, } \\
\text { Philippines, Poland, South } \\
\text { Africa }\end{array}$ \\
\hline $\begin{array}{l}\text { Study to Describe the Safety, } \\
\text { Tolerability, } \\
\text { Immunogenicity, and } \\
\text { Efficacy of RNA Vaccine } \\
\text { Candidates Against } \\
\text { COVID-19 in Healthy Indi- } \\
\text { viduals }\end{array}$ & $2 / 3$ & A & BioNTech SE|Pfizer & $\begin{array}{l}\text { USA, Argentina, Brazil, } \\
\text { Germany, South Africa, } \\
\text { Turkey }\end{array}$ \\
\hline $\begin{array}{l}\text { Phase III Double-blind, } \\
\text { Placebo-controlled Study of } \\
\text { AZD1222 for the Preven- } \\
\text { tion of COVID-19 in Adults }\end{array}$ & 3 & A & AstraZeneca | Iqvia Pty Ltd & $\begin{array}{l}\text { Argentina; Chile; Colombia; } \\
\text { Czechia; France; Germany; } \\
\text { India; Italy; Netherlands; } \\
\text { Peru; Spain; USA }\end{array}$ \\
\hline $\begin{array}{l}\text { A Study of Ad26.COV2.S for } \\
\text { the Prevention of } \\
\text { SARS-CoV-2-Mediated } \\
\text { COVID-19 in Adult Partic- } \\
\text { ipants (ENSEMBLE) }\end{array}$ & 3 & A & $\begin{array}{c}\text { Janssen Vaccines \& } \\
\text { Prevention B.V. }\end{array}$ & $\begin{array}{l}\text { USA; Chile; Colombia; } \\
\text { Mexico; Peru; Brazil; South } \\
\text { Africa }\end{array}$ \\
\hline $\begin{array}{l}\text { A Study of Ad26.COV2.S for } \\
\text { the Prevention of } \\
\text { SARS-CoV-2-mediated } \\
\text { COVID-19 in Adults (EN- } \\
\text { SEMBLE 2) }\end{array}$ & 3 & $\mathrm{R}$ & $\begin{array}{c}\text { Janssen Vaccines \& } \\
\text { Prevention B.V. }\end{array}$ & $\begin{array}{l}\text { Belgium, Brazil, Colombia, } \\
\text { France, Germany, } \\
\text { Philippines, South Africa, } \\
\text { Spain, UK, USA }\end{array}$ \\
\hline $\begin{array}{l}\text { COVID-19: a Phase } 2 \mathrm{a} \text {, } \\
\text { partially observer-blind, } \\
\text { multicenter, controlled, } \\
\text { dose-confirmation clinical } \\
\text { trial to evaluate the safety, } \\
\text { reactogenicity and immu- } \\
\text { nogenicity of the investiga- } \\
\text { tional SARS-CoV- } 2 \\
\text { MRNA vaccine cvncov in } \\
\text { adults }>60 \text { years of age and } \\
18 \text { to } 60 \text { years of age }\end{array}$ & 2 & A & CureVac Ag & Brazil; Panama; Peru \\
\hline
\end{tabular}

$R$ recruiting, $N$ not yet recruiting, $A$ active, not recruiting

Source: clinicaltrials.gov Database and COVID-19-living NMA initiative

Elaborated by the authors

\section{Discussion}

Our results indicate that a concerning geopolitical scenario is emerging, with developed countries and three BRICS' countries (China, India, and Russia) dominating the development and production of patented vaccines, active principles (APIs) and adjuvants, leaving developing countries, in greatest need, with very limited vaccine stocks. 
Table 7 COVID-19 vaccines: development partnerships in India, Brazil, and South Africa

\begin{tabular}{lll} 
Institution (country)/vaccine & COVID-19 vaccine: development partnerships & Note: vaccine/vaccine can- \\
\cline { 2 - 3 } $\begin{array}{ll}\text { or vaccine candidate } \\
\text { India }\end{array}$ & $\begin{array}{l}\text { South Bate } \\
\text { Africa }\end{array}$ & \\
& & Brazil
\end{tabular}

Fiocruz/Instituto De
Tecnologia De
Imunobiológicos (Brazil)

Akers Biosciences Inc. (USA) and Premas biotech (India)

Beximco Pharmaceuticals Ltd. (Bangladesh)

\section{Bharat Biotech \\ (India)/University Of \\ Wisconsin-Madison and FluGen (USA) \\ Biological E Limited (India) and Ohio State Innova- tion Foundation (USA)}

Instituto Butantan (Brazil)
Codagenix Inc. (US)/CDX 005

Etna Biotech (the European research arm of Zydus Cadila (India)

Gennova Biopharmaceuticals (India)/HGCO19

Indian Institute of Technology and Hester Biosciences (India)

Mynvax, Bharat Biotech, Serum Institute of India, and Cadila Healthcare (Zydus Cadila) (India) Novavax (USA)/Covovax

PFIZER (USA)
Development Partnership: vaccine prototype completed

Investment in Serum Institute of India-development of COVID-19 vaccine

Development and testing of a intranasal vaccine

License to the "novel live attenuated measles virus vectored vaccine candidates"

Africa

\section{Technology - Transfer \\ from AstraZen-}

eca

$$
\text { eca }
$$

Collaboration for vaccine _ _ _ _ _ n $\quad$ _ntranasal, live-attenuated development with Serum Institute of India

Working in measles vaccines for COVID-19

"First vaccine based on messenger ribonucleic acid (mRNA) platform"

Development of a vaccine versus COVID-19

Development of a vaccine

Collaboration for the development: Serum Institute of India; Indian Council of Medical Research (ICMR)

India as arsenal to the vaccine development (announced by the company)
The candidate is stable at $2-8^{\circ} \mathrm{C}$ : easier logistics

"Based on recombinant avian paramyxovirus-based vector platform"

The collaboration extends for COVISHIELD (a vaccine candidate for COVID-19-co-developed by AstraZeneca and Oxford University 
Table 7 (continued)

\begin{tabular}{|c|c|c|c|c|}
\hline \multirow{2}{*}{$\begin{array}{l}\text { Institution (country)/vaccine } \\
\text { or vaccine candidate }\end{array}$} & \multicolumn{3}{|c|}{ COVID-19 vaccine: development partnerships } & \multirow{2}{*}{$\begin{array}{l}\text { Note: vaccine/vaccine can- } \\
\text { didate }\end{array}$} \\
\hline & India & $\begin{array}{l}\text { South } \\
\text { Africa }\end{array}$ & Brazil & \\
\hline $\begin{array}{l}\text { Pune-Based Serum Institute } \\
\text { of India (India); Max } \\
\text { Planck Institute for Infec- } \\
\text { tion Biology and Vaccine } \\
\text { Projekt Management } \\
\text { (Germany) }\end{array}$ & $\begin{array}{l}\text { Evaluation of tuberculosis } \\
\text { vaccine for COVID-19 } \\
\text { vaccine }\end{array}$ & - & - & - \\
\hline União Química (Brazil) & - & - & Pilot Scale & $\begin{array}{l}\text { Russian Direct Investment } \\
\text { Fund (RDIF) (Russia)/- } \\
\text { Sputnik V }\end{array}$ \\
\hline Zydus Cadila (India) & $\begin{array}{l}\text { Development of vaccine } \\
(*) \text { : two methods }\end{array}$ & - & - & $\begin{array}{l}\text { Method 1: "DNA vaccine } \\
\text { versus viral membrane } \\
\text { protein"; Method 2. "Live } \\
\text { attenuated recombinant } \\
\text { measles virus vectored } \\
\text { vaccine against } \\
\text { COVID-19" }\end{array}$ \\
\hline Zydus Cadila (India) & $\begin{array}{l}\text { Development: Two } \\
\text { candidate vaccines }\end{array}$ & - & - & $\begin{array}{l}1 \text { live attenuated } \\
\text { recombinant measles } \\
\text { vaccine and } 2 . \text { DNA } \\
\text { vaccine }\end{array}$ \\
\hline
\end{tabular}

(*)Including this country

Source: Chemical Business New Base (CBNB) in STN International (January, 2021), INPI.gov.br; Butantan.gov. br; UniãoQuímica.com.br

Elaborated by the authors

Consequently, as recently confirmed by the WHO Director-General in the Parliamentary Assembly of the Council of Europe (PACE), 75\% of global vaccine doses are concentrated in just 10 countries [4]. Our results also indicate the dynamism and proactivity of India in the production and clinical trials of different vaccines (Tables 7 and 8). Among the three agro-based countries in our study (India, South Africa, and Brazil), India has by far a leading protagonist role in the vaccine preparedness. Our study provides evidence that this post-COVID scenario tends to be dramatic for developing countries, particularly in other two BRICS's and agro-dependent countries examined here (South Africa and Brazil). It will be necessary otherwise to conceive novel governance strategies to strengthen local manufacturing capacity in these countries, supporting vaccine RD\&I institutes and manufacturers to incorporate new technologies for production of innovative products. Multinational and startup companies have the intellectual property of new vaccine technologies, adjuvants, and novel vaccine platforms, but often many of these companies do not have sufficient production capacity to meet the global demand for these products and rely on technological transfer to public and private manufacturers both in developed and developing countries to expand their production. Other important issues are the increasingly strict international vaccine regulatory requirements, which are pressuring developing countries' manufacturers for exponential investments in compliance, modernization, and 
Table 8 COVID-19 vaccines: production capacity in India, Brazil, and South Africa

\begin{tabular}{|c|c|c|c|c|}
\hline \multirow[t]{2}{*}{ Institution (country) } & \multicolumn{3}{|c|}{ COVID-19 vaccine: production } & \multirow[t]{2}{*}{ Note: vaccine/vaccine candidate } \\
\hline & India & $\begin{array}{l}\text { South } \\
\text { Africa }\end{array}$ & Brazil & \\
\hline Aurobindo Pharma (India) & $\begin{array}{l}\text { Vaccine production } \\
\text { plant }\end{array}$ & - & - & $\begin{array}{l}\text { The company builds a production } \\
\text { facility for viral vaccines }\end{array}$ \\
\hline Fiocruz (Brazil) & - & - & $\begin{array}{l}\text { Vaccine's } \\
\text { production }\end{array}$ & AstraZeneca's vaccine \\
\hline Hetero Biopharma (India) & $\begin{array}{l}\text { Production of Sputnik } \\
\text { (COVID-19 } \\
\text { vaccine) }\end{array}$ & - & - & - \\
\hline Instituto Butantan & - & - & $\begin{array}{l}\text { Vaccine's } \\
\text { production }\end{array}$ & $\begin{array}{l}\text { Sinovac Biotech (CoronaVac } \\
\text { Vaccine) }\end{array}$ \\
\hline $\begin{array}{l}\text { Panacea Biotec (India) and } \\
\text { Refana Inc. (USA) }\end{array}$ & $\begin{array}{l}\text { Development, } \\
\text { production, and }\end{array}$ & - & - & - \\
\hline $\begin{array}{l}\text { Note: A joint venture is in } \\
\text { the Republic Of Ireland }\end{array}$ & commercialization & & & \\
\hline $\begin{array}{l}\text { Serum Institute of India } \\
\text { (India) }\end{array}$ & $\begin{array}{l}\text { To export vaccines } \\
\text { and collaboration } \\
\text { with GAVI (The } \\
\text { Vaccine Alliance) }\end{array}$ & - & - & $\begin{array}{l}\text { Production of } 2 \text { billions doses } \\
\text { (approximately) around } \\
\text { June 2021. The company } \\
\text { teamed up with many countries }\end{array}$ \\
\hline $\begin{array}{l}\text { Serum Institute of India and } \\
\text { Indian Council of } \\
\text { Medical Research } \\
\text { (India)/Novavax (USA) }\end{array}$ & $\begin{array}{l}\text { Manufacturing } \\
\text { capacity expanded }\end{array}$ & - & - & $\begin{array}{l}\text { Based on a Matrix-M adjuvant } \\
\text { and protein }\end{array}$ \\
\hline
\end{tabular}

(*)Including this country

Source: Chemical Business New Base (CBNB) in STN International (January, 2021), Butantan.gov.br, Portal. Fiocruz.br

Elaborated by the authors

capacity-building to meet these requirements, although resources in these countries are often insufficient to comply to them [54].

\section{Future Scenarios}

Our study evidences that a breakthrough scenario has emerged, in a new era of vaccine development, the Vaccinology 4.0 revolution, with accelerated development of disruptive technologies contributing to a new paradigm in vaccine development, such as for instance, the new mRNA, engineered viral vector and peptide-based vaccine platforms. These novel vaccines platforms radically differ from the previous traditional ones, allowing rapid and readily scalable production, with high productivity and flexibility, in which the same process can be used to produce vaccines against different indications. We have now several COVID-19 vaccines authorized in different countries and policy makers often question if it would possible to predict which vaccines will perform the best in real-world against the recent concerning variants (United Kingdom B.1.1.7; South-Africa B.1.351; Brazil P1). We consider that it is not possible to compare these vaccines and predict their performance, at this point it 
would certainly be premature. Although there a few preliminary results and pre-print publications indicating that some vaccines might be effective against these three more worrying COVID-19 variants, many unknown issues related to nature and duration of immunity and protection remain in the scientific agenda to be clarified. Current SARS-CoV-2 vaccines were designed for earlier coronavirus versions. Some scientists, based on these preliminary results and pre-print publications, believe they might also protect against these new variants, but the extent of this protection is not clear yet. We list below the vaccines that might offer some protection against these COVID-19 variants:

1. Pfizer/BioNTech - preliminary results suggest this vaccine protects against these new variants, but there are some indications that the vaccine could be slightly less effective for these variants.

2. Moderna - preliminary results indicate that this vaccine is effective against the South Africa variant, but it is not clear how strong and long-lasting could be the immune response.

3. Oxford/AstraZeneca - preliminary results suggest it protects against the new UK variant. It offers less protection against the South Africa variant, although there are indications it could protect against severe illness.

4. Novavax and Janssen vaccines - there are preliminary results indicating that these two vaccines might offer some protection against these variants.

The emergence of more severe and lethal variants of COVID-19, exponentially aggravating the current pandemic scenario is a real possibility with potentially huge global economic impact and should be a topic of major global concern, requiring urgent redesign of vaccines. The development of an universal SARS-CoV-2 that would protect against all variants ("pan-CoV vaccine'), as supported now by NIAID/NIH, should be a global priority, receiving urgently massive funding and incentives, in an unprecedented effort to intensify international and national collaborations on innovative universal vaccine development, leaded by WHO, COVAXFacility, GAVI, CEPI and financially supported by G-7, G-20, The World Economic Forum, the World Bank, the World Trade Organization (WTO), Gates Foundation and other organizations. Developing countries' scientists and manufacturers should be active players in these global initiatives supporting technological transfer agreements for local production, to accelerate vaccine development against these variants.

Finally, for future scenarios, the issue of access should also be considered. It should be recognized that the novel mRNA vaccines (Pfizer/BioNTech and Moderna) are extraordinary breakthroughs, a revolution in vaccine development and a new era in Vaccinology. Their efficacy is greater, with few adverse events, as stated by CDC in a recent document. Nevertheless, there are some constraints, particularly in developing countries, for their immediate incorporation into National Immunizations ProgramsNIPs. Besides the very high prices of these multipatented vaccines [55] there are other infrastructure and logistic constraints, particularly with the Pfizer/BioNTech vaccine, such as the requirement of refrigeration under minus $75 \mathrm{C}$ and once taken out kept refrigerated and used within five days. These constraints are particularly severe in countries of continental dimensions such as Brazil and India, with limited vaccine purchasing capacity and the need to transport these vaccines by road or by river to indigenous and rural communities in distant locations. For the above mentioned 
reasons, the development of universal and more accessible vaccines against all variants ("pan-CoV vaccine"), which is also an issue for future Influenza vaccines and other vaccines for potentially pandemic diseases, should be of utmost priority. If approved, these universal vaccines could completely change the future scenario for pandemics.

\section{Conclusion}

The COVID-19 pandemic came at a time that the global community was preparing for a circular economy transition by 2050, as illustrated by the recent European Union Circular Economy Action Plan [56]. Our results indicate that an extensive range of breakthrough SARS-CoV-2 vaccines (mRNA, engineered viral vector and peptide-based) emerged in this scenario just nine months after the onset of the pandemic, inaugurating a new era in vaccine development, in the context of Vaccinology 4.0. These novel vaccines are, for their potentially huge economic impact, a crucial circular bioeconomy component and a key strategy for the transition towards a prevention-oriented, resource-saving and sustainable world. Our results also indicate a great concentration of multipatented vaccines in developed countries, with two BRICS' countries leading the development and production of patented active pharmaceutical ingredients-API and adjuvants (India and China) and a pro-active dynamism of India in vaccine production and clinical trials. This concentration, aggravated by a complex global geopolitical scenario in which just 10 countries account for $75 \%$ of global COVID-19 vaccine doses, is dramatically restricting access to vaccines by populations in the poorest countries. Without universal access to SARS-CoV-2 vaccines and other vaccines for potentially pandemic diseases, the world will continue to submerge in a long-standing pandemic scenario, permeated by economic depression, social exclusion and extreme poverty, compromising equity, human rights and environmental sustainability. Although it should be recognized that the poorest countries, such as Brazil and South Africa, are now gradually incorporating the new SARS-CoV-2 vaccines into their National Immunization Programs (NIP), with financial support from the COVAX-Facility, GAVI Alliance, WHO, Gates Foundation and other international organizations, this inclusive donor strategy, in spite of its highly positive results, has limitations in supporting local manufacturing and innovation capacity, constraining local vaccine self-sufficiency and achievement of Sustainable Development Goals (SDG). Finally, as indicated in our future scenarios, the emergence of concerning new SARS-CoV-2 variants, such as the ones in UK, Brazil and South Africa, which are now exponentially aggravating the pandemic, will require an urgent redesign of COVID-19 vaccines, with new funding mechanisms in support to an effective global pandemic preparedness system. In this new system, an innovative global vaccine preparedness strategy is urgently needed, in the direction of a sustainable and resource-saving circular bioeconomy. Finally, our results also indicate, that in order to support this new global vaccine preparedness strategy, developing countries should be active players not only in clinical trials of multinational companies but in sustainable local vaccine RD\&I and production. 
Acknowledgements The authors thank Bio-Manguinhos of Oswaldo Cruz Foundation, the School of Chemistry of the Federal University of Rio de Janeiro and the National Institute of Industrial Property for the support. We also thank Rafael Cavalcante dos Santos, M. Sc., School of Chemistry, Federal University of Rio de Janeiro for the Figures and final art.

Author Contribution All authors contributed to the study conception and design. Material preparation, data collection, and analysis were performed by Alessandra Oliveira, Adelaide Antunes, Cristina Mendes, Suzanne Schumacher, and Mateus Ramos. The first draft of the manuscript was written by Cristina Possas, Adelaide Antunes, and Akira Homma, and all authors commented on previous versions of the manuscript. All authors read and approved the final manuscript.

Data Availability Not applicable.

Code Availability Not applicable.

\section{Declarations}

Ethics Approval Not applicable.

Consent to Participate Not applicable.

Consent for Publication Not applicable.

Conflict of Interest The authors declare no competing interests.

\section{References}

1. World Health Organization (2018) Circular bioeconomy and health: opportunities and risks. WHO/Europe, Geneva. https://www.euro.who.int/en/publications/abstracts/circular-economy-and-health-opportunitiesand-risks-2018. Accessed February 232021.

2. Cutler DM, Summers LH (2020) The COVID-19 pandemic and the \$ 16 trillion virus. JAMA 2020 324(15):1495-1496

3. World Health Organization (2021a) Draft landscape of COVID-19 candidate vaccines. WHO. http://www. who.int/blueprint/priority-diseases/key-action/list-of-candidate-vaccines-developed-against-ncov.pdf. Accessed February 232021

4. World Health Organization (2021b) Declaration of WHO Director General to Parliamentary Assembly of the Council of Europe (PACE) Covid-19 vaccines must be a 'global public good, available to everyone, everywhere'. https://pace.coe.int/en/news/8184/covid-19-vaccines-must-be-a-global-public-good-availableto-everyone-everywhere. Accessed April 52021.

5. Baden LR, El Sahly HM, Essink B et al (2020) Efficacy and safety of the mRNA-1273 SARS-CoV-2 vaccine. N Engl J Med 384:403-416. https://doi.org/10.1056/NEJMoa2035389

6. Polack FP, Thomas SJ, Kitchin N, Absalon J, Gurtman A, Lockhart S, Perez JL, Pérez Marc G, Moreira ED, Zerbini C, Bailey R, Swanson KA, Roychoudhury S, Koury K, Li P, Kalina WV, Cooper D, Frenck RW Jr, Hammitt LL, Türeci Ö, Nell H, Schaefer A, Ünal S, Tresnan DB, Mather S, Dormitzer PR, Șahin U, Jansen KU, Gruber WC, C4591001 Clinical Trial Group (2020) Safety and efficacy of the BNT162b2 mRNA COVID-19 vaccine. N Engl J Med 383:2603-2615. https://doi.org/10.1056/NEJMoa2034577

7. Logunov DY, Dolzhikova IV, Shcheblyaokov DV et al (2021) Safety and efficacy of an rAd26 and rAd5 vector-based heterologous prime-boost COVID-19 vaccine: an interim analysis of a randomized controlled phase 3 trial in Russia. Lancet 397(10275):671-681. https://doi.org/10.1016/S0140-6736(21)00234-8

8. Voysey M, Clemens SAC, Madhi SA, et al (2021) Safety and efficacy of the ChAdOx1 nCoV-19 vaccine (AZD1222) against SARS-CoV-2: an interim analysis of four randomised controlled trials in Brazil, South Africa, and the UK. Lancet 397:99-111. https://doi.org/10.1016/S0140-6736(20)32661-1 
9. Liu C, Zhou Q, Li Y, Garner LV, Watkins SP, Carter LJ, Smoot J, Gregg AC, Daniels AD, Jervey S, Albaiu D (2020) Research and development on therapeutic agents and vaccines for COVID-19 and related human coronavirus diseases. ACS Central Sci 6:315-331. https://doi.org/10.1021/acscentsci.0c00272

10. Wajnberg A, Amanat F, Firpo A, Altman DR, Bailey MJ, Mansour M, McMahon M, Meade P, Mendu DR, Muellers K, Stadlbauer D, Stone K, Strohmeier S, Simon V, Aberg J, Reich DL, Krammer F, Cordon-Cardo C (2020) Robust neutralizing antibodies to SARS-CoV-2 infection persist for months. Science 370(6521): 1227-1230. https://doi.org/10.1126/science.abd7728

11. Edridge AWD, Kaczorowska J, Hoste ACR, Bakker M, Klein M, Loens K, Jebbink MF, Matser A, Kinsella CM, Rueda P, Ieven M, Goossens H, Prins M, Sastre P, Deijs M, van der Hoek L (2020) Seasonal coronavirus protective immunity is short-lasting. Nat Med 26:1691-1693. https://doi.org/10.1038/s41591020-1083-1

12. Iwasaki A (2021) What reinfections mean for COVID-19. Lancet Infect Dis 21:3-5. https://doi.org/10.1016/ S1473-3099(20)30783-0

13. Kim JH, Marks F, Clemens JD (2021) Looking beyond COVID-19 vaccine phase 3 trials. Nat Med 27:205211. https://doi.org/10.1038/s41591-021-01230-y

14. Mishra PK, Pal PK, Joshi CM (2020) Mangalmay Institute of Engineering and Technology. SARS-COV: control and prevention (SARS-COV) newly isolated human coronavirus and real time status share to global location. IN Patent 202011016574A

15. Sinha K (2020) Vaccine for novel corona virus. IN Patent 202031014832A

16. Arvind S, Devika SV, Joshi CM, Jain V, Singh Y and Singh V (2020) Methods and compositions for infectious RNA, CDNA, and MRNA of SARS coronavirus. IN Patent 202041016724A

17. Dubey R, Tomar P, Chundawat TS, Kumar R, Mal D, Kathayat K (2020) Coronavirus (COVID-19) diagnostic reagents kits. IN Patent 202011018851A.

18. Ramkumar K, Kavitha JC, Kaur G, Vinitha JC (2020) Corona virus diagnostic reagents treatment kits and share the patient real time location, condition using deep learning programming. IN Patent 202011024811A

19. Lohagaonkar KS, Lohagaonkar MK (2020) Inactivated COVID-19 vaccine. IN Patent 202021024459A

20. Smith G, Liu Y, Massare M, Novavax INC (2016) Immunogenic Middle East respiratory syndrome coronavirus (MERS COV) compositions and methods. IN Patent 201617013371A

21. Weiner DB, Muthumani K, Sardesai NY (2016) The Trustees of The University of Pennsylvania. In: MERS COV vaccine, IN Patent 201617021769A

22. Kyratsous C, Stahl N, Sivapalasingam S, Regeneron Pharmaceuticals INC (2016) Human antibodies to middle east respiratory syndrome coronavirus spike protein. IN Patent 201647039008A

23. Stary G, Radovic-Moreno AF, Basto PA, Starnbach MN, Langer R (2015) President and Fellows of Harvard College, Massachusetts Institute of Technology and The Brigham and Women's Hospital INC. In: Nanoparticle-based compositions, IN Patent 201503426P2

24. Stedman KM, Laidler JR, Bahjat K (2015) Portland State University, Providence Health \& Services Oregon. In: Immunogenic compositions comprising silicified virus and methods of use, IN Patent 201506559P1

25. Yan Z, Engelhardt JF, Qiu J (2015a) University of Iowa Research Foundation, The University of Kansas. In: Chimeric adeno-associated virus/ bocavirus parvovirus vector, IN Patent 201510078P1

26. Daoust MA, Couture M, Lavoie PO and Vezina LP, Medicago INC (2013a). Virus like particle production in plants. IN Patent 201305009P4

27. Leclerc D, Savard P, Folia Biotech INC (2013) Virus like particles and process for preparing same. IN Patent 201310534P1

28. Hora M, Novartis AG (2012a) Improved methods for preparing squalene. IN Patent 201203534P2

29. Fotin-Mleczek M, Voss S, Curevac AG (2010) Composition comprising a complexed (M) RNA and a naked MRNA for providing or enhancing an immunostimulatory response in a mammal and uses thereof. IN Patent 291696B

30. Thess A, Schlake T, Probst J, Curevac GMBH (2014) Nucleic acid comprising or coding for a histone stemloop and a poly(A) sequence or a polyadenylation signal for increasing the expression of an encoded pathogenic antigen. IN Patent 201404812P1

31. Sahin U, Haas H, Vogel A, Erbar S, Walzer K (2020) Biontech RNA Pharmaceuticals GMBH, TRON Translationale Onkologie an der Universitatsmedizin der Johannes Gutenberg - Universitat Mainz GGMBH. In: Formulation for administration of RNA, IN Patent 202047028961A

32. Seeberger PH, Stallforth P, De Libero G, Cavallari M (2014) Max Planck Ges Foerderung Wissenschaften, Univ Basel Hospital. In: Carbohydrate glycolipid conjugate vaccines, IN Patent 201408326P1

33. Fotin-Mleczek M, Kallen KJ, Probst J, Curevac GMBH (2015) Combination of vaccination and inhibition of the pd 1 pathway. IN Patent 201506225P1

34. Lauterbach H, Hochrein H and Sanos S (2017) Bavarian Nordic A/S. Methods and compositions for intra nasal immunization with recombinant MVA encoding flagellin. IN Patent 201717009706A 
35. Roos T, Kunze M, Yazdan Panah B, Yilmaz S, Conzelmann M (2018) Curevac. In: Method for producing RNA molecule compositions, IN Patent 201817022402A

36. Kido H and Mizuno D (2012) The University of Tokushima. Mucosal vaccine. IN Patent 201207596P1

37. Chen H, Zheng M, Wang P, Lau J and Yeun K, Emerging Viral Vaccine Limited, Hk and| Versitech Limited (2018) Cold adapted and virulence factor deleted live attenuated vaccine suitable for mucosal delivery. IN Patent 201817042073A

38. Yan Z, Engelhardt JF, Qiu J, Univ Iowa Res Found, Univ Kansas (2015b) Chimeric adeno-associated virus/ bocavirus parvovirus vector. ZA Patent 201507946B

39. Daoust MA, Couture M, Lavoie PO and Vezina LP, Medicago INC (2013b). Virus like particle production in plants. ZA Patent 201305407B

40. Daoust MA, Couture M, Lavoie PO, Vezina LP, Mareukeu AD, Piereu OR, Ruiseu PB, Dau MA, Jarnikov D, Wajs AA, Medicago INC, Irdeto BV (2014) Producing virus like particle used in composition for preventing and/or treating viral infections e.g. rabies, by introducing nucleic acid comprising active regulatory region into plant, and incubating plant under favorable conditions. ZA Patent 201400166B

41. Hora M, Novartis AG (2012b) Improved methods for preparing squalene. ZA Patent 201208381B

42. Baker S, Deng X, Hackbart M, Mettelman R, Mielech A, O'brien A, Faaberg K and Lager KM, Loyola University Chicago, The United States of America as Represented By The Secretary of Agriculture (2018) Coronavírus, vacinas compreendendo os mesmos, e métodos para a prevenção de doença. BR Patent 112019018251A2

43. Stedman KM, Laidler JR, Bahjat K (2014) Portland State University. In: Composições imunogênicas compreendendo vírus silificado e métodos de uso, BR Patent 112015017966A2

44. Stary G, Radovic-Moreno AF, Basto PA, Starnbach MN, Langer RS, Farokhzad OC, Andrian UV (2014) President and Fellows of Harvard College. In: Composições à base de nanopartículas, BR Patent 112015021970A2

45. Smith G, Liu Y, Massare M, Novavax INC (2014) Composições imunogênicas e métodos com coronavírus da síndrome respiratória do oriente médio (MERS-COV). BR Patent 112016006122A2

46. Kyratsous C, Stahl N, Sivapalasingam S, Regeneron Pharmaceuticals INC (2015) Anticorpos humanos para a síndrome respiratória do oriente médio - proteína de superfície. BR Patent 112016025009A2

47. Daoust MA, Couture M, Lavoie PO and Vezina LP, Medicago INC (2011) Produção de partícula tipo vírus em plantas. BR Patent 112013016185A2

48. Hora M, Novartis AG (2011) Métodos para a fabricação de uma emulsão de óleo em água, para a preparação de um kit de vacina e para redestilação de uma composição compreendendo 99\% de esqualeno ou mais, assim como emulsão de óleo em água e kit. BR Patent 112012028711

49. Thess A, Schlake T, Probst, J, Curevac GmbH (2013) Ácido nucleico que compreende ou codifica uma alça peduncular de histona e uma sequência poli(a) ou um sinal de poliadenilação para aumentar a expressão de um antígeno patogênico codificado. BR Patent 112014016361A2

50. Seeberger PH, Stallforth P, De Libero G, Cavallari M (2013) Universitätsspital Basel. In: Composto da fórmula geral (i): A[L-CH-CA]P e formulação de vacina, BR Patent 112014023193A2

51. Fotin-Mleczek M, Kallen KJ, Probst J, Curevac GmbH (2014) Combinação de vacinação e inibição da via de PD-1. BR Patent 112015018989A2

52. Kido H and Mizuno D (2011) The University of Tokushima. Vacina de mucosa produtora de uma liga de mucosa antígeno-específica e igg do sangue e método para produzir uma vacina de mucosa produtora de uma IGA de mucosa antígeno-específica e uma IGG do sangue. BR112012022059A2

53. Zhou D, Si L, Zhou X, Zhang Z, Xu H, Tian Z, Zhang C, Xiao S, Xia Q, Zhang L (2016) Peking University. In: Vírus mutantes, método de preparação e uso dos mesmos, BR Patent 112018013168A2

54. Possas C, Martins RM, Homma A (2020) Vaccine innovation and global sustainability. In: Ademola AA, Chertow MR, EHM M, Pannell D (eds) Science Technology and Innovation for Sustainable Development Goals: Insights from Agriculture, Health, Environment and Energy, 1st edn. Oxford University Press, New York, pp 219-242

55. Possas C, de Souza Antunes A, Mendes F et al (2015) Access to new technologies in multipatented vaccines: challenges for Brazil. Nat Biotechnol 33:599-603. http://www.nature.com/doifinder/10.1038/nbt. 3244

56. European Commission (2020) Circular economy action plan for a cleaner and more competitive Europe. https://ec.europa.eu/environment/circular-economy/index_en.htm. Accessed 26 September 2020 


\section{Affiliations}

Cristina Possas $^{1} \cdot$ Adelaide Maria de Souza Antunes $^{2,3} \cdot$ Alessandra Moreira de Oliveira ${ }^{2,3}$ - Cristina d'Urso de Souza Mendes Santos ${ }^{3} \cdot$ Mateus Pinheiro Ramos $^{2}$. Suzanne de Oliveira Rodrigues Schumacher ${ }^{2}$. Akira Homma ${ }^{1}$

1 Bio-Manguinhos, Oswaldo Cruz Foundation, Rio de Janeiro, Brazil

2 School of Chemistry, Federal University of Rio de Janeiro, Rio de Janeiro, Brazil

3 National Institute of Industrial Property, Rio de Janeiro, Brazil 